\title{
ANNA PORCZYŃSKA-CISZEWSKA
}

\section{Intellectual Disability and Experiencing Happiness}

\begin{abstract}
Anna Porczyńska-Ciszewska, Intellectual Disability and Experiencing Happiness. Interdisciplinary Contexts of Special Pedagogy, no. 24, Poznań 2019. Pp. 51-66. Adam Mickiewicz University Press. ISSN 2300-391X. DOI: https:/ / doi.org/ 10.14746/ikps.2019.24.03
\end{abstract}

Although it may be challenging to unambiguously recognize and define it, the notion of experiencing happiness, a constituent of psychological well-being, is undoubtedly one of the key traits featuring every person, whether intellectually fit or disabled. The feeling of happiness plays a significant role when coping with various types of situations including also the circumstances faced by an intellectually disabled person. Due to the diversity and multeity of the dimensions where it occurs, the experience of happiness can be subject of analyses from various stances, including the viewpoint of an intellectually disabled person. It seems that the disabled individual's ability to deal with difficulties, which also influences efficiency of the rehabilitation process, is actually determined by the feelings of happiness, content and optimism, all of which remain in a relation with one's personality, life situation, and conditions in which they live. The article draws attention to the subject of experiencing happiness by and psychological well-being of intellectually disabled people. It emphasizes the possibility of both theoretical and practical applications of assumptions of positive psychology as a requisite condition for the optimization of functioning of intellectually disabled people. Beyond any doubt, due care for the intellectually disabled people's experience of happiness and psychological wellbeing is one of the most crucial requirements of their rehabilitation process as "positive states of mind (...) provide the power to struggle with adversities of life" 1 .

KEY WORDS: experiencing happiness, psychological well-being, intellectual disability

${ }^{1}$ J. Czapiński, Czy szczesście poptaca? Dobrostan psychiczny jako przyczyna pomyślności życiowej, [in:] Psychologia pozytywna. Nauka o szczęściu, zdrowiu, sile $i$ cnotach człowieka, ed. J. Czapiński, PWN, Warszawa 2004, p. 235. 


\section{Foreword}

The pursuit of happiness is undoubtedly one of the basic rights of every human being. The right to happiness is even provided for in the United States Declaration of Independence of 1776, where we read that: "We hold these truths to be self-evident, that all men are created equal, that they are endowed by their Creator with certain unalienable Rights, that among these are Life, Liberty and the pursuit of Happiness" 2 . It is worth noting that the pursuit of happiness is not limited only to abled persons, but it is guaranteed to all men, including disabled persons. This is confirmed by the opinion of James S. Mill, who believes that it is better to be Socrates dissatisfied than a fool satisfied. This opinion, of course, may be interpreted in may different ways, but it shows that both the sage and the fool, the sick and the healthy, the rich and the poor, the fortunate and the unfortunate one have equal chances to find, in the stream of their own experiences, the sense of their life and the corresponding happiness ${ }^{3}$.

When discussing the happiness experienced by persons with intellectual disabilities, it is worth quoting Władysław Tatarkiewicz, who said that "Some need more, others need less to be happy, but the happiness of that who is satisfied with little is no less or no smaller happiness than the happiness of that who demands a lot from life" 4 . Thus, the problem of the psychological well-being of persons with disabilities, especially intellectual disregarded, seems very important, though often disregarded. This is also confirmed by the fact that the vast majority of studies on intellectual disabilities focuses on negative issues, associated mainly with the problems of persons with intellectual disabilities, their deficits, diseases and impairments caused by disability. Thus, it seems necessary to shift

2 United States Declaration of Independence of 1776.

${ }^{3}$ A. Porczyńska-Ciszewska., Cechy osobowości a doświadczanie szczęścia i poczucie sensu życia, Wydawnictwo Uniwersytetu Śląskiego, Katowice 2013.

${ }^{4}$ W. Tatarkiewicz, O szczęściu, Państwowe Wydawnictwo Naukowe, Warszawa 1965 , p. 45. 
the focus of the theory of disability, research and practice to its positive aspects.

It is also worth noting that psychological well-being plays a very important motivational role. According to the onion theory of happiness - it is not only or not so much the effect of life experiences and actions but, in the first place, it determines those experiences and actions as well as their results. Janusz Czapiński claims that the advantages of positive emotional states, satisfaction with life and optimism are quite measurable and objective, and the life of a happy persons looks completely different than that of an unhappy one. One could state that "happiness is like a lottery ticket - it is a chance to win a prize" 5 . The prize may take many different forms - it could be good interpersonal relations, health, professional success, material goods - shortly speaking - anything that people dream of, strive for and believe to be the promise of "real happiness" 6 .

To sum up, it could be claimed that happy people can more effectively strive for better living conditions or minimize stress in life compared to those who are less happy ${ }^{7}$. It seems then that the psychological well-being, whose indicator is a sense of happiness, is an important mechanism for intellectually disabled persons to cope with the problems caused by their disability.

\section{Happiness experienced by persons with intellectual disabilities}

When undertaking to discuss the subject of happiness and how it is understood and defined, it could be said that a precise and unequivocal definition of the concept of "happiness" seems unattaina$b^{8}{ }^{8}$. Despite the fact the scholars have been trying to determine what happiness is since Antiquity to this day, the problem remains

\footnotetext{
${ }^{5}$ J. Czapiński, Czy szczęście popłaca..., p. 237.

6 Ibidem, p. 237.

${ }^{7}$ Ibidem, p. 51-102.

${ }^{8}$ A. Porczyńska-Ciszewska, op. cit.
} 
unsolved, because issues that relate to happiness and psychological well-being lie at the border of many different sciences on human nature and may be analyzed from various scientific perspectives.

The problems of the psychology of happiness, psychological well-being and the sense of life have already been studied by ancient philosophers, followed by theologians, psychologists, sociologists, anthropologists, psychiatrists, educators and even historians and writers. In recent years, this subject-matter has been of interest for psychologists in the positive psychology trend initiated in late 20th century by Martin Seligman.

His positive psychology is about happiness and self-fulfillment, it highlights the strengths of a person and deals with the problems of a contemporary human being who looks for ways to live a happy, successful and meaningful life 9 .

Positive psychologists look for answers to the basic questions concerning both the psychological and existential condition of the human being. They try to answer questions like: What affects the feeling of happiness and why some people are more content with life than others? What should a person do and be guided by so that their own happiness does not reduce the happiness of others, who also affect their own happiness?

This type of questions seem to be important from the perspective of persons with disabilities, also intellectual disabilities, especially given the fact that there are few scientific studies on the psychological well-being or feeling happiness and its role in life as well as in the process of rehabilitating persons with intellectual disabilities.

When it comes to happiness, in a search for its definition, it seems relevant what saint Augustine said about time: "it is something we are all familiar with but cannot really define it"10. Many

${ }^{9}$ M. Seligman, Psychologia pozytywna, [in:] Psychologia pozytywna. Nauka o szczęściu, zdrowiu, sile i cnotach człowieka, ed. J. Czapiński, Wydawnictwo Naukowe PWN, Warszawa 2004.

10 J. Czapiński, Psychologia szczęścia. Przegląd badań i zarys teorii cebulowej, Pracownia Testów Psychologicznych Polskie Towarzystwo Psychologiczne, Warszawa 1994 , p. 6. 
researchers have tried to define the concept of happiness, but none of them managed to form its one and only, irrefutable definition. Thus, speaking of happiness, one should bear in mind the equivocality of the term and distinguish different concepts of happiness from one another. However, despite the existing differences, they all have on thing in common, namely, they all mean something positive and precious ${ }^{11}$.

In order to systematize the significance of the concept of happiness, it could be arranged in two dimensions: the level of activation and the degree of objectivity. As far as the first dimension is concerned, happiness covers sensations from a low level of activation (e.g. contentment, psychological balance, peace of mind) to a high level of activation (e.g. joy, excitation, ecstasy). The other dimension is associated with determining the emotional state on the basis of internal (subjective) or external (objective) criteria. For example, even though contentment and joy differ in terms of the level of activation, both emotions have an inevitable subjective component - one of the most reliable of their indicators are self-descriptions ${ }^{12}$. This classification of the co of "happiness" is presented in table 1.

Table 1. Four concepts of happiness

\begin{tabular}{|c|c|c|}
\hline \multirow{2}{*}{ Level of activation } & \multicolumn{2}{|c|}{ Level of objectivity } \\
\cline { 2 - 3 } & $\begin{array}{c}\text { subjective } \\
\text { (good mood) }\end{array}$ & $\begin{array}{c}\text { objective } \\
\text { (doing the right thing) }\end{array}$ \\
\hline High & joy & eudaimonia \\
\hline Low & contentment & peace of mind \\
\hline
\end{tabular}

Source: J.R. Averill, T.A. More, Szczęście, [in:] Psychologia emocji, ed. M. Lewis, J.M. Haviland-Jones, Gdańskie Wydawnictwo Psychologiczne, Gdańsk 2005

11 W. Tatarkiewicz, op. cit.

12 J.R. Averill, T.A. More, Szczęście, [in:] Psychologia emocji, ed. M. Lewis, J.M. Haviland-Jones, Gdańskie Wydawnictwo Psychologiczne, Gdańsk 2005. 
According to this classification, we can identify: happiness as joy (a state of strong activation accompanied by good mood), happiness as contentment (low level of activation accompanied by good mood), happiness as peace of mind (low level of activation accompanied by a sense of doing the right thing) and happiness as eudaimonia (an emotional state associated with full engagement in an actvity that is very important for a person, or with an optimal level of its performance; this is so-called optimal state of full engagement).

\section{Intellectual disability from the perspective of positive psychology}

When discussing intellectual disability, it should be mentioned that, in recent years, there has been a major change in defining and explaining the phenomenon, which could be described as a shift from the medical to the social model. This change makes it possible to apply the assumptions and theory of the positive psychology to understanding and explaining disability ${ }^{13}$.

For many years, the dominant approach to disability assumed an apparent lack of diversity in the group of persons with disabilities and accentuated the assumption of the universality of disabled persons' experiences, this way discriminating and marginalizing this social group. According to the assumptions of the medical model, disability was treated as personal tragedy, an individual trait of a given person, and the problems encountered by persons with disabilities were perceived as the direct cause of their disease or damage. According to this model, both the diagnosis and treatment should be based on medical knowledge and classifications of disabilities should focus on identifying the biological limitation ${ }^{14}$.

${ }^{13}$ M.L. Wehmeyer, The Oxford Handbook of Positive Psychology and Disability, Oxford University Press, New York 2013.

14 Z. Kazanowski, Społeczny wymiar wspótczesnej koncepcji niepetnosprawności intelektualnej, ANNALES Universitatis Mariae Curie-Skłodowska, Lublin-Polonia, Vol. XXVIII, 2015, no. 1, p. 33-43. 
The modern and different from the former approach to disability introduces a positive paradigm to the thinking about disability and underlines the importance of applying, in research and in practice, the assumptions of positive psychology as a condition for the optimization of functioning and supporting persons with disabilities ${ }^{15}$. In the social model, disability is defined as the consequence of social, economic and physical barriers encountered by a disabled person in their environment. One could say that the ideas contained in the social model constitute foundations for the concept of social integration of individuals with disabilities, because they question the contribution of biological factors to the etiology of disability ${ }^{16}$. Disability regarded from the perspective of the social model requires not so much treatment (as was assumed in the medical model) but changes in the society.

An example of such new approach are definitely the models of disability presented by the World Health Organization (WHO) in the International Classification of Functioning, Disability and Health (ICF). This classification resigns from the traditional perception of disability in anatomic categories and replaces it with thinking about disability in functional categories, focusing on what a person with disability may achieve and searching for methods to support disabled persons in achieving their aspirations.

It is worth highlighting the innovative character of the ICF, which classifies "health components" (rather than disease), this way emphasizing the positive elements and the functions that an individual may perform in association with them. In this classification, a very important role is played by elements that comprise the wellbeing of a person, i.e. their good psychological and physical condition. Apart from the ICF, a new approach to disability is also accentuated by the United Nations Convention on the Rights of Persons with Disabilities, which constitutes the main set of international values necessary for the implementation of a positive policy towards persons with disabilities.

15 M.L. Wehmeyer, op. cit.

16 Z. Kazanowski, op. cit. 
Also, the assumptions of the contemporary concept of intellectual disability developed by Robert L. Schalocka ${ }^{17}$ refer to the social model of disability and are in line with the International Classification of Functioning (ICF). According to the definition proposed by R.L. Schalock "intellectual disability is characterized by significant limitations both in intellectual functioning and in adaptive behavior as expressed in conceptual, social, and practical adaptive skills. Such disability originates during the developmental period"18. The definition in itself may seem to have nothing in common with the social model, but the assumptions accompanying the definition, considered to be important for its implementation, explicitly highlight the social aspect of intellectual disability. According to these assumptions, limitations in the current functioning must be analyzed in the context of the peer community and the culture. Moreover, a proper evaluation should take into consideration cultural and linguistic diversity as well as differences in the communication process and sensory, motor and behavioral factors. Another assumption, according to which limitations coexist with strengths in each individual, accentuates an analysis of the phenomenon from the perspective of positive psychology. At the same time, it is assumed that an important element in the characteristics of limitations is to develop a profile of the required support and that proper support provided to an individual with intellectual disability over a longer period of time results in improved functioning ${ }^{19}$. These assumptions evidently highlight the need to take into consideration the social context of intellectual disability. It can be claimed then tat intellectual disability is not a phenomenon that is subject to the same criteria of evaluation in every conditions. The social community may either expose differences, speaking in the clinical terms, or present an attitude of acceptance for otherness, this way marginalizing it ${ }^{20}$.

17 R.L. Schalock et al, Intellectual Disability. Definition, Classification and Systems of Supports (11 th Edition), AAIDD, Washington 2010.

18 Ibidem, p. 1.

19 Ibidem.

20 Z. Kazanowski, op. cit. 
Adopting a positive perception of disability, including intellectual disability, may undoubtedly be interpreted as a process of meeting half-way the various needs of persons with disabilities by increasing their involvement in all the areas of social life, while at the same time eliminating various forms of social exclusion.

\section{Experiencing happiness as a forerunner of successful therapy of persons with intellectual disabilities}

Experiencing happiness, which is a fundamental element of psychological well-being, undoubtedly constitutes one of the most important (if not the most important) driving factors of human activity that enables a person to undertake all kinds of activity and helps one find their way in the reality and choose their goals and methods of action. The psychological well-being, happiness and contentment, and having a sense of purpose in life, i.e. positive mental states, play an extremely important motivational function they empower a person to cope with adversities, stimulating success in life, which, in turn, make a person happy. The research conducted so far clearly suggests that happy persons are better-off - have better interpersonal relations, better health and longer life, earn more money and enjoy professional successes - just because they are hap$\mathrm{py}^{21}$. The advantages of strengthening the subjective psychological well-being, a sense of happiness being one of its indicators, are evident both for individual and social functioning of not only abled persons but also persons with physical or intellectual disabilities.

Thus, it is vital to analyze the links between psychological wellbeing, measured, among other things, by experiencing happiness, with the success and effectiveness of the therapy of persons with intellectual disabilities. Accordingly, this article focuses mainly on the problem of happiness as experienced by persons with intellectual disabilities and its role in the process of their rehabilitation.

${ }^{21}$ A. Porczyńska-Ciszewska, op. cit. 
Even though the way people think about intellectual disabilities changes, persons suffering from various kinds of disabilities are very often threatened by social isolation and their communities not infrequently expect from them behavior that goes beyond standards. We also observe a tendency to undervalue the developmental possibilities of those persons and to expose limitations associated with intellectual disabilities. Undoubtedly, limits are often imposed on the development and social functioning of persons with intellectual disabilities and the state of disability is deepened as a result of handicapping external conditions. Viewing this social group as persons of limited usefulness and capacity results in their being associated with marginalizing social roles ${ }^{22}$. The relatively low awareness of the consequences of social degradation of persons with intellectual disabilities poses obstacles to social simulation, as a result of which, there are no possibilities to live and independent and active life. Because of such attitude to the intellectually disabled, we forget that the development of those persons is generally conditioned by the same principles and mechanisms as apply to abled persons ${ }^{23}$.

Undoubtedly, the important elements of the quality of life that can affect the rehabilitation and enabling of persons with disabilities are: a sense of happiness, contentment and psychological wellbeing. According to research, feeling happiness may be considered as one of the most important prerequisites of success in various area of human activity, health condition, pro-social attitude and motivation to collaborate with other people $\mathrm{e}^{24}$. Thus, it seems that actions focusing on helping people, both abled and disabled, so that they may feel more happiness, should be one of the tactics both in the

22 Z. Gajdzica, Dystans społeczny wobec osób z upośledzeniem umysłowym jako czynnik determinujacy ich marginalizację, "Chowanna” 2012, 1, p. 83-92.

${ }^{23}$ L. Bakiera, Ż. Stelter, Wspomaganie rozwoju osób niepetnosprawnych intelektualnie, [in:] Diagnoza potrzeb i modele pomocy dla osób z ograniczeniami sprawności, ed. A. Brzezińska, R. Kaczan, K. Smoczyńska, Wydawnictwo Naukowe Scholar, Warszawa 2010, p. 143-162.

24 E. Diener, R.E. Lucas, C. Napa Scolon, Beyond the hedonic treademill. Revising the adaptation theory of well-being, "American Psychologist" 2006, 5, p. 305-314. 
prevention and rehabilitation processes. This is confirmed by what Martin Seligman said in a speech inaugurating the positive trend in psychology: "Treatment is not just fixing what is broken; it is nurturing what is best" 25 . These words definitely apply to the rehabilitation of persons with intellectual disabilities, where a special focus should be placed on what is best in a person.

According to the assumptions of positive psychology, the key element of helping people who suffer, are in a crisis situation and display mental disorders are interactions that aim to reveal and develop their mental abilities to cope with difficulties, and in particular, their mental strength. The goal of such approach is to improve the sense of well-being and to provide a person not only with the ability to cope with existing problems but also to increase their threshold of resistance to future difficulties. The psychotherapy and mental rehabilitation methods developed within positive psychology differ from the traditional ones in that, instead of focusing on weaknesses and deficits, they emphasize the resources one has ${ }^{26}$. Positive psychology assumes that, by introducing interactions aimed at developing resources to clinical interventions, it is possible not only to improve the quality of patients' life much more and for much longer, but also to avoid the risks of a helping model that centers only around what is irregular and disadvantageous in the functioning and environment of a person ${ }^{27}$.

Taking care of the psychological well-being and increasing the feeling of happiness are undoubtedly important aspects of the rehabilitation of persons with intellectual disabilities, since "positive states of mind (...) empower one to overcome adversities" 28 . Positive emotions, which are strongly associated with experiencing

${ }^{25}$ E. Trzebińska, Psychologia pozytywna, Wydawnictwa Akademickie i Profesjonalne, Warszawa 2008, p. 135.

${ }^{26}$ M. Seligman, T. Steen, N. Park, C. Peterson, Positive psychology progress: Empirical validation of interventions, "American Psychologist" 2005, 60, p. 410-421.

${ }^{27}$ E. Trzebińska, Psychologia pozytywna, Wydawnictwa Akademickie i Profesjonalne, Warszawa 2008.

28 J. Czapiński, Czy szczęście popłaca..., p. 235. 
happiness, openly signal new possibilities, which stimulates broadening of the field of vision and reaching beyond a ready-made repertoire of habitual thoughts and actions ${ }^{29}$, which is most probably very significant in rehabilitation and therapy. By opening a person to new possibilities, positive emotions have another adaptive advantage, namely they enrich resources that help cope with stressful situations. Increasing knowledge, possessions and the repertoire of activities contributes to the development of sustainable personal resources, while the enrichment of resources reduces susceptibility to threats, thus increasing changes for experiencing more positive emotions. This mechanism undoubtedly contributed to the effectiveness of therapy and rehabilitation of persons with intellectual disabilities whose development, as was mentioned above, is determined by the same principles and mechanisms that apply to abled individuals. For this reason, working to increase the feeling of happiness seems to be an important element of therapy and rehabilitation since, as Barbara Fredrickson says, the feeling of happiness not only results from successful life but also - or perhaps most importantly - builds success, which means that happiness if the main author of happiness ${ }^{30}$. In association with the above, it could be said that the feeling of happiness is one of the main prerequisites of successful life, which stimulates the achievement of life goals ${ }^{31}$, and one of such goals may also be positive effects of rehabilitation that persons with disabilities strive to achieve.

It is also worth noting one of currently the most popular and most intensely verified hypotheses, associated with the new and quickly developing field of science, namely psychoimmunology or psychoneuroimmunology According to this hypothesis, well-being may affect the immunity of an organism, this way determining the

${ }^{29}$ B.L. Fredrickson, Positive emotions, [in:] Handbook of positive psychology, ed. C.R. Snyder, S.J. Lopez, Oxford University Press, New York 2002.

30 Ibidem.

31 Czapiński J., Psychologiczne teorie szczęścia, [in:] Psychologia pozytywna. Nauka o szczęściu, zdrowiu, sile i cnotach człowieka, ed. J. Czapiński, PWN, Warszawa 2004. 
risk of illness through the direct impact of the brain on the immune system, i.e. the "body's brain". If an illness develops all the same, the coupling mechanism between the immune system and the psychic may weaken (positive emotions) or strengthen (negative emotions) the symptoms of the illness, may accelerate or delay the healing process, and facilitate or hinder psychological adaptation to chronic disorders ${ }^{32}$ such as, for example, disorders caused by disability, including intellectual disability.

To sum up, it could be said that knowledge about the feeling of happiness and psychological well-being may be used to create various educational and rehabilitation programs, in vocational training or free time designing. Also, such knowledge may undoubtedly be used by clinical psychologists, especially those engaged in psychotherapy, treating extreme lack of happiness or clinical depression (previous research on psychological well-being contributed to the development of many depression treatment methods) ${ }^{33}$. Elements of knowledge concerning the quality of life, happiness and contentment may also be used by educators, also in special needs education, since, as Mihaly Csikszentmihalyi suggests ${ }^{34}$, they are used in the rehabilitation of juvenile offenders, organizing activities in senior homes or occupational therapy for retarded persons.

\section{Conclusions}

Experiencing happiness, which is one of the most important components of psychological well-being, constitutes an exceptional-

${ }^{32}$ L. Kamel-Siegel, J. Rodin, M. Seligman, J. Dwyer, Explanatory style and cell-mediated immunity, "Health Psychology" 1991, 10, p. 229-235; M.F. Scheier, S.C. Carver, Effects of optimism on psychological and physical well-being. Theoretical overview and empirical update, "Cognitive Therapy and Research" 1992, 16, p. 201-228.

33 A. Porczyńska-Ciszewska, op. cit.

${ }^{34}$ M. Csikszentmihalyi, Przeptyw. Jak poprawić jakość życia. Wydawnictwo Studio Emka, Warszawa 1996; M. Csikszentmihalyi, Urok codzienności. Psychologia emocjonalnego przeptywu, Wydawnictwo CiS, Warszawa 1998. 
ly complex and subjective phenomenon, at whose foundations lies a huge repertoire of factors associated both with the features of a given person and, to a much lesser extent, with their specific context. A person with intellectual disability and their context are undoubtedly unique and require special treatment, taking into account the positive perspective.

It is also worth noting that research and analyses concerning disability in various areas of positive psychology, such as the quality of life, the sense of contentment and well-being, optimism, hope or handling things and making one's own decisions are an interesting and important research area, since the advantages associated with subjective good mood are evident. These advantages concern not only abled, but also disabled persons. The development of the science of positive psychology is of no little impact on other scientific disciplines, such as the education of persons with disabilities. Applying positive psychology in research on intellectual disability certainly enriches the traditional approach that focuses mainly on the negative aspects of disability.

It would be just to claim that knowledge of the mechanisms that translate happiness into happy life is a necessary condition for the success of all prophylactic, educational, therapeutic and corrective activities. Knowledge concerning the feeling of happiness, contentment with life and optimism is so important that the feeling of happiness is as if a self-fulfilling prophecy, as it constitutes the basic source of creative motivation driving human activity, contributing to the successful life of a happy individual and improving the quality of their existence ${ }^{35}$. For this, apparently simple, though in fact much more complicated reason, continued analysis of the feeling of happiness and psychological well-being of persons with intellectual disabilities constitutes an important and relevant research problem.

${ }^{35}$ A. Porczyńska-Ciszewska, op. cit. 


\section{Bibliography}

Averill J.R., More T.A., Szczęście, [in:] Psychologia emocji, ed. M. Lewis, J.M. Haviland-Jones. Gdańskie Wydawnictwo Psychologiczne, Gdańsk 2005.

Bakiera L., Stelter Ż., Wspomaganie rozwoju osób niepetnosprawnych intelektualnie, [in:] Diagnoza potrzeb i modele pomocy dla osób z ograniczeniami sprawności, ed. A. Brzezińska, R. Kaczan, K. Smoczyńska, Wydawnictwo Naukowe Scholar, Warszawa 2010, p. 143-162.

Csikszentmihalyi M., Przeptyw. Jak poprawić jakość życia, Wydawnictwo Studio EMKA, Warszawa 1996.

Csikszentmihalyi M., Urok codzienności. Psychologia emocjonalnego przeptywu. Wydawnictwo CiS, Warszawa 1998.

Czapiński J., Psychologia szczęścia. Przeglad badań i zarys teorii cebulowej, Pracownia Testów Psychologicznych Polskie Towarzystwo Psychologiczne, Warszawa 1994.

Czapiński J., Czy szczęście poptaca? Dobrostan psychiczny jako przyczyna pomyślności życiowej, [in:] Psychologia pozytywna. Nauka o szczęściu, zdrowiu, sile i cnotach człowieka, ed. J. Czapiński, Wydawnictwo Naukowe PWN, Warszawa 2004.

Czapiński J., Psychologiczne teorie szczęścia, [in:] Psychologia pozytywna. Nauka o szczęściu, zdrowiu, sile i cnotach człowieka, ed. J. Czapiński, Wydawnictwo Naukowe PWN, Warszawa 2004.

Diener E., Lucas R.E., Napa Scolon C., Beyond the hedonic treademill. Revising the adaptation theory of well-being, "American Psychologist" 2006, no. 5, p. 305-314.

Fredrickson B.L., Positive emotions, [in:] Handbook of positive psychology, ed. C.R. Snyder, S.J. Lopez, Oxford University Press, New York 2002.

Gajdzica Z., Dystans społeczny wobec osób z upośledzeniem umysłowym jako czynnik determinujący ich marginalizacje, "Chowanna” 2012, 1, p. 83-92.

Kamel-Siegel L., Rodin J., Seligman M., Dwyer J., Explanatory style and cell-mediated immunity, "Health Psychology" 1991, no. 10, p. 229-235.

Kazanowski Z., Społeczny wymiar wspótczesnej koncepcji niepetnosprawności intelektualnej. Annales Universitatis Mariae-Curie-Skłodowska. Lublin-Polonia 2015, vol. XXVIII, 1.

Porczyńska-Ciszewska A., Cechy osobowości a doświadczanie szczęścia i poczucie sensu życia, Wydawnictwo Uniwersytetu Śląskiego, Katowice 2013.

Schalock R.L. et al, Intellectual Disability. Definition, Classification, and Systems of Supports. 11 ${ }^{\text {th }}$ Edition, AAIDD, Washington 2010.

Scheier M.F., Carver S.C., Effects of optimism on psychological and physical well-being. Theoretical overview and empirical update, "Cognitive Therapy and Research" 1992, no. 16, p. 201-228.

Seligman M., Psychologia pozytywna, [in:] Psychologia pozytywna. Nauka o szczęściu, zdrowiu, sile i cnotach człowieka, ed. J. Czapiński, Wydawnictwo Naukowe PWN, Warszawa 2004. 
Seligman M., Steen T., Park N., Peterson C., Positive psychology progress: Empirical validation of interventions, "American Psychologist" 2005, no. 60, p. 410-421.

Tatarkiewicz W., O szczęściu, Państwowe Wydawnictwo Naukowe, Warszawa 1965. Trzebińska E., Psychologia pozytywna, Wydawnictwa Akademickie i Profesjonalne, Warszawa 2008.

Wehmeyer M.L., The Oxford Handbook of Positive Psychology and Disability, Oxford University Press, New York 2013. 